\title{
Empirical Assessment of Factors Influencing Corporate Performance of China's Independent Brand Automobile Companies
}

\author{
Maoguo $\mathrm{Wu}^{1} \&$ Zhenyu $\mathrm{Wu}^{1}$ \\ ${ }^{1}$ SHU-UTS SILC Business School, Shanghai University, Shanghai, China \\ Correspondence: Zhenyu Wu, SHU-UTS SILC Business School, Shanghai University, 20 Chengzhong Road, Jiading \\ District, Shanghai 201899, China.
}

Received: November 21, 2017

Accepted: January 26, $2018 \quad$ Online Published: March 13, 2018

doi:10.5430/ijfr.v9n2p96

URL: https://doi.org/10.5430/ijfr.v9n2p96

\begin{abstract}
China's independent brand automobile is an infant industry in China. It is characterized by a small share in the world market and low price with unreliable quality. However, continuous expansion of China's population, an increase in the number of high-end consumers, coupled with rapid economic development, serve altogether to promise China's independent brand automobile companies a bright future. In October 2014, China introduced a favorable policy that low-exhaust models (1.6L and below) pay half of previous purchase tax. Afterwards, China's independent brand automobile industry experienced a booming period. Nevertheless, the gradual degradation of policy dividend, changes in market environment, and consumer awareness, have compelled China's independent brand automobile companies to adjust their original business model and to innovate accordingly so as to meet new market demand.

This paper empirically investigates factors influencing corporate performance of China's independent brand automobile companies. It utilizes data of all 18 listed China's independent brand automobile companies between 2012 and 2016. Factors assessed include capital scale, enterprise growth rate, capital turnover rate, enterprise solvency, research and development expenditure input intensity, sales channel, human resources etc. Empirical results find that the scale of the company, the growth rate of total assets, the growth rate of net profit, the profit margin of core business, the operating profit margin, the current ratio, the quick ratio, the intensity of research and development investment, and the ratio of highly educated employees, are the key factors which enhance corporate performance of China's independent brand automobile companies.
\end{abstract}

Keywords: China's independent brand automobile companies, corporate performance, panel data

\section{Introduction}

With progress in global industrialization, China's automobile industry has developed rapidly and gone beyond the stage of imitation. It has innovated considerably and gradually started building up its own brand. After decades of development, the scale of China's automobile industry has expanded significantly. China's independent brand automobile companies have successfully developed all kinds of automobiles that own proprietary intellectual property rights, and, compared with automobile imports, they have the advantage of lower prices so that sales volume increases year by year both in the Chinese market and in the international market, attracting a great deal of capital inflows.

The automobile market in China has grown remarkably as well. By the end of 2016, automobile sales volumes had been continuously ranked the first of the world eight years in a row. From 2007 to 2016, China's car ownership increased from 57 million to 185 million, where the compound annual growth rate achieved $14.0 \%$. In the first quarter of 2017, when the total market increased about 1.7\%, the sales volume of China's independent brand automobile grew $7.3 \%$. China's independent brand automobile industry is one of the most important manufacturing industries in China. It affects the productivity of the whole country and influences the financial capital flows. All the figures above show that the growth of China's automobile industry presents a major opportunity for its independent brands.

This paper empirically investigates factors influencing corporate performance of China's independent brand automobile companies. It selects 18 representatives of China's independent brand automobile companies and analyzes their performance indicators from 2012 to 2016. Factors such as capital scale, enterprise growth rate, capital 
turnover rate, enterprise solvency, research and development expenditure input intensity, sales channel, human resources etc. are assessed. Empirical results find that the scale of the company, the growth rate of total assets, the growth rate of net profit, the profit margin of core business, the operating profit margin, the current ratio, the quick ratio, the intensity of research and development investment, and the ratio of highly educated employees, altogether serve to enhance the corporate performance of China's independent brand automobile companies. Meanwhile, receivables, inventory turnover and main sales channels have no significant effects on performance. Policy implications based on empirical results may help China's independent brand automobile companies to improve internal management and take larger market shares.

The remaining part of this paper is organized as follows. Section 2 reviews the related literature. Section 3 introduces the institutional background and the data. Section 4 is devoted to empirical analysis. Section 5 interprets empirical results and proposes policy implications. Section 6 then concludes the paper.

\section{Related Literature}

In terms of the corporate performance assessment of automobile companies, Lebas (1995) argues that performance is an important indicator measuring whether a company successfully achieves budgeted goals. Walker (1985) defines performance more comprehensively. He proposed that corporate performance is primarily reflected by market coverage of products and services such as market position; corporate performance can also be reflected by indicators such as return on assets etc. as input-output ratio; or it can be reflected by sales including revenue totals and to main customers as an anti-risk capability. It follows, then, that the primary methods for corporate performance assessment are Return on Assets (ROA), Return on Equity (ROE), and Earnings per Share (EPS).

In terms of the research, a great deal of studies pertain to factors of technological innovation. Based on the evaluation model of technological innovation and corporate performance, Chong (2016), for example, analyzes the financial data of China's automobile manufacturing companies' annual reports from 2010 to 2014. Empirical results show that innovation ability in various aspects of the company can have positive effects on corporate performance. Moreover, Chen (2015) finds that both different innovative systems and innovative strategies have positive effects on long-term corporate performance of automobile companies.

Previous studies were frequently preoccupied with investigating capital factors. Han (2011) established multiple linear regression model for examining the relationship between assets-liability ratio and corporate performance. Empirical results show that the size of the enterprise has the strongest correlation with automobile companies' corporate performance, followed by the proportion of floating stocks. Li (2009) analyzed data of listed automobile manufacturing companies from 2006 to 2008, and explored the intrinsic relationship between capital structure and corporate performance. Li ultimately finds that a certain liability scale is conducive to the establishment of financial leverage, which may enhance companies' earnings per share.

On the other side of the equation, some scholars have also evaluated factors of human and intellectual resources. In that pursuit, Li and Zhang (2010) studied the relationship between corporate performance and proportions of technical staff and staff with a university degree or above through linear regression. Results show that a significant positive correlation exists between human and intellectual capital of listed automobile manufacturing companies and ROA. Yang (2016) adopts the method of multiple linear regression for studying the relationship between the coefficient of human capital gain and the corporate performance of listed automobile manufacturing companies from 2008 to 2011, and finds that a positive correlation exists between the two.

As can be seen from the aforementioned studies, representative indicators of measuring corporate performance mainly constitute ROA, ROE and EPS. For a capital-intensive industry like the automobile manufacturing industry, the effectiveness of capital utilization determines companies' corporate performance. It is therefore reasonable to use ROA to measure corporate performance. Previous research on factors influencing corporate performance mainly focus on financial data such as operating cost, profit, asset-liability ratio etc., based on the accounting period hypothesis. Nevertheless, these data only reflect companies' operational levels at the end of each accounting period, neglecting a key part of the dynamic level of capital flows. This paper therefore considers additional influencing factors like growth indicators based on important financial data.

In terms of research methods, factorization and DEA analysis are widely used in related literature, yet both entail obvious pitfalls. Linear regression on factorized dependent variable neglects the influence of unit root, and, as a result, the possibility of spurious regression arises. Although the DEA model reduces dimensionality when processing data, input and output variables are, more often than not, selected subjectively. This paper attempts to 
empirically assess influencing factors of corporate performance of China's independent brand automobile companies (proxied by ROA) by using panel data.

\section{The Data}

After decades of reform and development, a lot of independent brands have emerged in China's automobile market. Sales of these automobile brands have been increasing year by year, but China's independent brand automobile companies find it difficult to lift up their market positions. The main reason is that at the beginning of the development of China's independent automobile brands, the global automobile industry had already established itself. Due to the lack of brand effect at that time, China's independent brand automobile companies had to imitate and bid, contributing to failure in building up their own brands along the way.

By the end of 2016, there were 23 listed automobile companies in China. This paper selects 22 companies that produce independent brand automobiles over the period of 2012 to 2016. Companies with negative shareholders' equity are removed due to the fact that when shareholders' equity is negative and at the same time assets are fewer than liabilities, the company may break up. Companies whose shareholders' equity fluctuates drastically due to debt restrictions or mergers/acquisitions are also removed. Companies with abnormal sales are removed. Mostly abnormal sales results from poor internal management and incomplete published information. Following these criteria, 4 companies are removed, resulting in 18 of China's mature independent automobile companies with stable performance and acceptable fluctuation. All sample companies have more than $95 \%$ market share based on operating revenues.

The data are gathered from annual reports and the Wind Database spanning 5 years, giving a total observation of 90 . Descriptive statistics are shown in Table 1.

Table 1. Descriptive statistics

\begin{tabular}{lllll}
\hline Variables & Mean & Standard Deviation & Minimum & Maximum \\
\hline End Balance of Total Assets & 555.89 & 2568.329 & 11.821 & 5906.28 \\
Return on Investment & 0.1706 & 1.54 & -3.22 & 13.6 \\
Growth Rate of Total Assets & 0.1879 & 0.15 & -0.14 & 0.82 \\
Growth Rate of Net Profit & -0.04 & 4.12 & -26.72 & 19.68 \\
Main Operation Profit Margin & 13.899 & 6.53 & -18.63 & 27.37 \\
Operating Profit Margin & 2.989 & 8.48 & -39.96 & 17.03 \\
Accounts Receivable Turnover & 62.19 & 131.40 & 1.4 & 894.64 \\
Inventory Turnover & 11.765 & 8.05 & 3.70 & 44.65 \\
Current Ratio & 1.25 & 1.23 & 0.61 & 12.30 \\
Quick Ratio & 0.9658 & 0.28 & 0.41 & 2.13 \\
Asset-liability Ratio & 62.29 & 15.33 & 30.08 & 94.88 \\
Research and Development Input & 0.039 & 0.017 & 0.0094 & 0.0874 \\
Percentage of Sales from Top Five & 0.369 & 1.48 & 0.041 & 13.47 \\
Customers & 0.309 & 0.15 & 0.0717 & 0.8138 \\
Percentage of Highly-Educated Staff & 0 & & & \\
\hline
\end{tabular}

As can be seen in Table 1, the scale of China's independent brand automobile companies is very large, totaling $¥ 5,500$ million in sum. However, companies’ total assets vary enormously, wherein the largest one achieves over $¥ 59,000$ million, a figure more than 50 times that of the smallest company valued at only $¥ 1,180$ million. Automobile companies usually own large quantity of buildings, lands, product lines, and inventory. The scale of total assets of automobile manufacturing company determines annual production and, furthermore, its economy of scale and market position. Large production scale is advantageous in the interest of saving costs and resources. It is thus reasonable to 
conclude that China's independent brand automobile companies should enlarge their assets scale in order to maintain competitiveness.

This paper measures growth level by total assets and growth rate of net profit. Overall, China's independent brand automobile companies have been maintaining a high growth rate, which is about $18 \%$ annually on average while the highest one achieved $82 \%$ and at the same time, very few companies experienced a decrease in total assets. The net profit growth rate does not seem to be as good as company scales. From 2012 to 2016 , the growth rate of net profit of China's independent brand automobile industry as a whole was decreasing year by year, mainly on account of the increase in labor cost and the decrease in products' profit margin. It follows then, that extending the scale alone cannot achieve the goal of long-term development.

Due to the high value of finished products, unsaleable inventory of automobile company can disrupt the cash flow. For that reason, the inventory turnover rate determines the capital circulation speed, especially for automobile manufacturers. The average automobile companies' inventory turnover rate is 11.7 , equivalent to a monthly turnover rate of the company's inventory, whereas companies with good performance enjoy a higher inventory turnover rate of 30 or more. This is similar to the performance of delivery of automobiles. Best-selling automobiles are often produced only after orders have been placed. This production method greatly reduces the warehousing and transportation costs of the inventory.

The intensity of research and development (R\&D) investment is the proportion of annual operation revenue accounted for by R\&D spending. R\&D expenditures of most independent brand automobile companies amount to about 4 percent of annual operating revenue, and they have been increasing year by year for the last five years. The data is highly disparate, however, with companies with good operating conditions investing highly in R\&D, while companies struggling with profit margins cope with limited R\&D spending. Because R\&D spending has an overall lag effect, companies that are performing well usually continue to invest more in $R \& D$, creating a virtuous cycle.

\section{Empirical Analysis}

This paper utilizes data of 18 listed independent automobile companies between 2012 and 2016. A panel data set is constructed to model and analyze influencing factors of corporate performance in terms of operation and management. A series of hypotheses are proposed as follows.

Hypothesis A: The scale of the independent brand automobile company has a positive overall effect on corporate performance. As automobile production entails considerable demand for raw materials and resources, the scale of the company directly affects its market position and bargaining power. A promising automobile company should thus have a considerable company scale.

Hypothesis B: The growth rate of total assets of independent brand automobile company has a positive effect on corporate performance. Song (2013) states that the automobile company's operation is based on capital, and total assets can reflect its operating scale and financial condition, whereas the growth rate of total assets constitutes an important indicator of growth.

Hypothesis C: The growth rate of net profit of independent brand automobile company has a positive effect on corporate performance. Net profit is the net value of revenue after deduction of costs and taxes. A higher growth rate of net profit indicates stronger profitability and growth.

Hypothesis D: The profit margin of core business on the part of the given independent brand automobile company has a positive effect on corporate performance. Profit margin is the ratio of operating profit and operating revenue. A high profit margin of core business indicates more competitive brand and higher additional value.

Hypothesis E: The profit margin of an independent brand automobile company has a positive effect on corporate performance. Profit margin shows the operating efficiency of a given company, which takes into account the impact that the operating costs have on operating efficiency.

Hypothesis F: The receivable turnover rate of an independent brand automobile company has a positive effect on corporate performance. High receivable turnover rate reflects rapid recovery of accounts receivable, and, in turn, high efficiency of transferring ledger assets into cash.

Hypothesis G: The inventory turnover rate of the independent brand automobile company has a positive effect on corporate performance. In addition, a higher level of automobile inventory directly leads to huge storage costs and inefficiency in capital circulation, critically disposing of the company's limited resources. An automobile company with a good operating performance should therefore have a high inventory turnover rate. 
Hypothesis $\mathrm{H}$ : The current ratio of an independent brand automobile company has a positive effect on corporate performance. The current ratio indicates the company's ability to pay debts through current assets before current liability expires, and, generally, is in direct proportion to solvency.

Hypothesis I: The quick ratio of independent brand automobile company has a positive effect on corporate performance. Similar to the current ratio, the quick ratio is also an important indicator of ability to pay debts, whereas it excludes effects of inventory and non-current assets expiring within 1 year.

Hypothesis J: The input of research and development of independent brand automobile company has a positive effect on corporate performance. China's independent brand automobile company is currently in a rapid growth stage and in need of a large amount of concomitant investment in order to remain cutting edge. Input of R\&D measures the creativity of company, and the company with better corporate performance should have higher R\&D investment intensity accordingly.

Hypothesis K: The percentage of sales from the top five customers of independent brand automobile company has a negative effect on corporate performance. A large percentage of sales from the top five customers indicates a narrow market channel, and the company bears higher sales risk as a result.

Hypothesis J: The educational background of the staff of independent brand automobile company has a positive effect on corporate performance. It is measured by the percentage of staff with an undergraduate qualification or above. Education demonstrates the initiative and innovative capacity of a given staff, indicating the growth potential of the company.

The corresponding variables of all hypotheses are described as follows.

Return on assets (ROA). It is the proxy of corporate performance. It is calculated as the total revenue divided by total assets. The formula is as follows:

\section{$\mathrm{ROA}=($ Total Profit + Interest Revenue $) /$ Total Assets}

where Total Assets is the ending balance of each company accounting period. ROA is a summative indicator of the balance sheet and the income statement. It shows the profitability of total assets and financial capital of a company. Meanwhile, the scales of total assets of automobile manufacturing companies tend to be very large, and ROA is quite representative for measuring their corporate performance.

Company size (SIZE). This variable is represented by ending the balance of total assets. Automobile companies are large-scale manufacturing enterprises. In order to maintain routine production and operation, they usually need to utilize a large amount of assets such as land, factories, large-scale automatic or semi-automatic production lines, welding and painting machinery and equipment, as well as a large number of products and large inventory. The scale determines the level of production of automobile companies, as well as the degree of market share. This paper studies the positive effect of company size on the performance of automobile companies.

Growth rate of total assets (EXPANSION). This variable is the annual growth rate of the end-balance of total assets, measuring the expansion capacity of core business. Maintaining a certain increase in growth rate is conducive to improving the company's market size, market position, and bargaining power. This paper studies the relationship between the growth of company size and the change in corporate performance accordingly.

Growth rate of net profit (NPGROWTH). Making profit and creating value constitute companies' primary objectives. Profitability indicators cannot be separated from the net profit shown in the income statement. The growth rate of net profit further reflects changes in corporate earnings.

Profit margin of core business (PROFITMARGIN). The profit margin of core business refers to the proportion of the core business income accounting for total income in a certain accounting period. It shows the profit brought by unit core business income. For automobile companies, the core business is the production and sales of vehicles. High profit margin of core business reflects high additional value of automobiles and an overall strong brand effect. This paper verifies the positive relationship between the profit margin of core business and corporate performance.

Profit margin of operation (OPERATIONMARGIN). The profit margin of operations is the proportion of operating profit accounting for the total operating income. It is an important indicator used to measure operating performance. It evaluates the profitability of enterprises taking into account operating costs.

Turnover rate of accounts receivable (AR). This is an important indicator of the recovery rate of receivables. A high turnover rate of accounts receivable indicates a high recovery rate of receivables, a high market position, low external pressure, and strong long-term development capability of automobile companies. This paper studies the impact of the turnover rate of accounts receivable on corporate performance. 
Inventory turnover rate (INVENTORY). For automobile companies, the unit value of products and finished goods is relatively high. The inventory turnover rate is therefore quite representative in the assessment of asset turnover rate. A high inventory turnover rate indicates strong realization ability of current assets. On the same token, operating efficiency is higher with stronger realization ability of current assets as well. This paper studies whether the inventory turnover rate has a positive impact on corporate performance.

Current ratio (CR). The ratio of current assets to current liabilities measures the ability of a company to repay short-term debt.

Quick ratio $(\mathrm{QR})$. This is the ratio of current assets after deduction of inventory and non-current assets expiring within 1 year, to current liabilities.

$R \& D$ investment intensity ( $R \& D)$. This is the proportion of $R \& D$ expenses accounting for annual operating income. It can show the company's attitude towards innovation. Theoretically, R\&D investment, despite the lag effect attached, nevertheless contributes to the improvement of core competitiveness. This paper explores the facilitation of $R \& D$ investment to a given automobile company.

Percentage of sales from top five customers (SALES). A high percentage of sales from the top five customers indicates that the company heavily relies on the top five customers, and the sales channel is so monotonous that the company is at a low market position.

Education of staff (EDU). It is measured by the percentage of staff with an undergraduate qualification or above. High qualification of staff contributes to the large intelligence capital of a company. Intelligence resources of a company are relevant in terms of both automobile manufacturing and research in new automotive technology. In this pursuit, abundant labor and intelligence resources can greatly promote the long-term development of company.

All variables are summarized in Table 2.

Table 2. Description of variables

\begin{tabular}{|c|c|c|}
\hline & Variables & Meanings \\
\hline Explained Variable & Return on Assets (ROA) & Ratio of Total Revenue to Total Assets \\
\hline \multirow{12}{*}{ Explanatory Variables } & Company Size (SIZE) & Ending Balance of Total Assets \\
\hline & $\begin{array}{l}\text { Growth Rate of Total Assets } \\
\text { (EXPANSION) }\end{array}$ & $\begin{array}{l}\text { Annual Growth Rate of Ending Balance of } \\
\text { Total Assets }\end{array}$ \\
\hline & 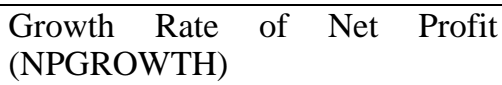 & Annual Growth Rate of Net Profit \\
\hline & $\begin{array}{l}\text { Profit Margin of Core Business } \\
\text { (PROFITMARGIN) }\end{array}$ & $\begin{array}{l}\text { Ratio of Net Profit to Total Revenue of } \\
\text { Core business }\end{array}$ \\
\hline & $\begin{array}{ll}\text { Profit } & \text { Margin } \\
\text { (OPERATIONMARGIN) } & \end{array}$ & Ratio of Net Profit to Total Revenue \\
\hline & $\begin{array}{l}\text { Turnover Rate of Accounts } \\
\text { Receivable (AR) }\end{array}$ & $\begin{array}{l}\text { Ratio of Sales Revenue to Average } \\
\text { Accounts Receivable }\end{array}$ \\
\hline & $\begin{array}{lll}\text { Inventory } & \text { Turnover } & \text { Rate } \\
\text { (INVENTORY) } & \end{array}$ & $\begin{array}{l}\text { Ratio of Operating Cost to Average } \\
\text { Inventories }\end{array}$ \\
\hline & Current Ratio (CR) & $\begin{array}{l}\text { Ratio of Current Assets to Current } \\
\text { Liabilities }\end{array}$ \\
\hline & Quick Ratio (QR) & Ratio of Liquid Assets to Current Liabilities \\
\hline & R\&D Investment Intensity (R\&D) & $\begin{array}{l}\text { Ratio of R\&D Expenses to Operating } \\
\text { Revenue }\end{array}$ \\
\hline & $\begin{array}{l}\text { Percentage of Sales from Top Five } \\
\text { Customers (SALES) }\end{array}$ & $\begin{array}{l}\text { Ratio of Sales from Top Five Customers to } \\
\text { Annual Sales }\end{array}$ \\
\hline & Education of Staff (EDU) & $\begin{array}{l}\text { Ratio of Staff with Undergraduate } \\
\text { Qualification or Above to Total Staff }\end{array}$ \\
\hline
\end{tabular}

ADF tests find that all variables are stationary. The Breusch \& Pagan Lagrangian Multiplier test finds, moreover, that the random effect model is better than OLS. F test finds that the fixed effect model is better than OLS. Then there's the Hausman test, which finds that a fixed effect model is better than a random effect model. On the other and, 
the Wald test detects a strong presence of heteroskedasticity. This paper therefore utilizes fixed effects with a control of heteroskedasticticity.

The econometric specification, ideally, would be of the following form:

$$
\begin{gathered}
\text { ROE }=\alpha+\beta_{1} \text { SIZE }+\beta_{2} \text { EXPANSION }+\beta_{3} \text { NPGROWTH }+\beta_{4} \text { PROFITMARGIN } \\
+\beta_{5} \text { OPERATIONMARGIN }+\beta_{6} \text { AR+ } \beta_{7} \text { INVENTORY }+\beta_{8} C R+\beta_{9} Q R+\beta_{10} R \& D+\beta_{11} \text { SALES }+\beta_{12} \text { EDU }+\varepsilon
\end{gathered}
$$

where $\alpha$ is intercept; $\beta_{\mathrm{i}}(\mathrm{i}=1,2,3,4,5,6,7,8,9,10,11,12)$ is the coefficient of a regression model; cis error term.

Regression results and robustness checks are shown in Table 3. Regression 1 is Ordinary Least Squares (OLS) with a control of heteroskedasticity. Regression 2 is Pooled OLS. Regression 3 is a fixed effect model with a control of heteroskedasticity. Regression 4 is an asymptotic fixed effect model. Regression 5 constitutes Panel Corrected Standard Errors (PCSE). This paper interprets Regression 3, regression of a fixed effect with control of heteroscedasticity as the empirical result.

\begin{tabular}{|c|c|c|c|c|c|}
\hline \multirow[b]{2}{*}{ Explanatory Variables } & \multicolumn{5}{|c|}{ Explained Variable: ROA } \\
\hline & $\begin{array}{l}\text { Regression } 1 \\
\text { Coefficient } \\
\text { (t-value) }\end{array}$ & $\begin{array}{l}\text { Regression } 2 \\
\text { Coefficient } \\
\text { (t-value) }\end{array}$ & $\begin{array}{l}\text { Regression } 3 \\
\text { Coefficient } \\
\text { (t-value) }\end{array}$ & $\begin{array}{l}\text { Regression } 4 \\
\text { Coefficient } \\
\text { (t-value) }\end{array}$ & $\begin{array}{l}\text { Regression } 5 \\
\text { Coefficient } \\
\text { (t-value) }\end{array}$ \\
\hline SIZE & $\begin{array}{l}0.003 \\
(4.80 \mathrm{e}-12)\end{array}$ & $\begin{array}{l}0.041 * * \\
(4.99 \mathrm{e}-12)\end{array}$ & $\begin{array}{l}0.251 \\
(7.20 \mathrm{e}-12)\end{array}$ & $\begin{array}{l}0.012 * * \\
(1.97 \mathrm{e}-12)\end{array}$ & $\begin{array}{l}0.001 * * * \\
(4.48 \mathrm{e}-12)\end{array}$ \\
\hline EXPANSION & $\begin{array}{l}0.000 * * * \\
(2.814)\end{array}$ & $\begin{array}{l}0.000 * * * \\
(0.979)\end{array}$ & $\begin{array}{l}0.014 * * \\
(2.76)\end{array}$ & $\begin{array}{l}0.001 * * * \\
(0.864)\end{array}$ & $\begin{array}{l}0.000 * * * \\
(2.186)\end{array}$ \\
\hline NPGROWTH & $\begin{array}{l}0.05^{* *} \\
(0.742)\end{array}$ & $\begin{array}{l}0.063^{*} \\
(0.085)\end{array}$ & $\begin{array}{l}0.01 * * * \\
(0.053)\end{array}$ & $\begin{array}{l}0.002 * * * \\
(0.02)\end{array}$ & $\begin{array}{l}0.001 * * * \\
(0.067)\end{array}$ \\
\hline PROFITMARGIN & $\begin{array}{l}0.057 * * \\
(0.130)\end{array}$ & $\begin{array}{l}0.206 \\
(0.167)\end{array}$ & $\begin{array}{l}0.241 \\
(0.172)\end{array}$ & $\begin{array}{l}0.008 * * * \\
(-0.418)\end{array}$ & $\begin{array}{l}0.002 * \\
(0.079)\end{array}$ \\
\hline OPERATIONMARGIN & $\begin{array}{l}0.436 \\
(0.124)\end{array}$ & $\begin{array}{l}0.07 * \\
(0.003)\end{array}$ & $\begin{array}{l}0.053 * * \\
(0.163)\end{array}$ & $\begin{array}{l}0.005 * * * \\
(0.059)\end{array}$ & $\begin{array}{l}0.077^{*} \\
(0.055)\end{array}$ \\
\hline $\mathrm{AR}$ & $\begin{array}{l}0.21 \\
(0.002)\end{array}$ & $\begin{array}{l}0.355 \\
(0.055)\end{array}$ & $\begin{array}{l}0.042 * * \\
(0.003)\end{array}$ & $\begin{array}{l}0.10 * \\
(0.003)\end{array}$ & $\begin{array}{l}0.361 \\
(0.004)\end{array}$ \\
\hline INVENTORY & $\begin{array}{l}0.268 \\
(0.054)\end{array}$ & $\begin{array}{l}0.336 \\
(0.044)\end{array}$ & $\begin{array}{l}0.291 \\
(0.054)\end{array}$ & $\begin{array}{l}-0.345 \\
(0.055)\end{array}$ & $\begin{array}{l}0.104 \\
(0.037)\end{array}$ \\
\hline $\mathrm{CR}$ & $\begin{array}{l}0.000 * * * \\
(0.086)\end{array}$ & $\begin{array}{l}0.000 * * * \\
(2.698)\end{array}$ & $\begin{array}{l}0.698 \\
(0.074)\end{array}$ & $\begin{array}{l}0.483 \\
(0.038)\end{array}$ & $\begin{array}{l}0.008 * * * \\
(0.183)\end{array}$ \\
\hline QR & $\begin{array}{l}0.002^{* * * *} \\
(1.8)\end{array}$ & $\begin{array}{l}-0.104 \\
(0.66)\end{array}$ & $\begin{array}{l}0.094 * \\
(2.052)\end{array}$ & $\begin{array}{l}0.027 * * \\
(1.066)\end{array}$ & $\begin{array}{l}0.000 * * * \\
(1.504)\end{array}$ \\
\hline $\mathrm{R} \& \mathrm{D}$ & $\begin{array}{l}0.014 * * \\
(31.419)\end{array}$ & $\begin{array}{l}0.048^{* *} \\
(28.03)\end{array}$ & $\begin{array}{l}0.002 * * * \\
(23.091)\end{array}$ & $\begin{array}{l}0.019 * * \\
(21.584)\end{array}$ & $\begin{array}{l}0.000 * * * \\
(17.333)\end{array}$ \\
\hline SALES & $\begin{array}{l}0.099 * \\
(1.706)\end{array}$ & $\begin{array}{l}0.173 \\
(1.72)\end{array}$ & $\begin{array}{l}0.623 \\
(1.167)\end{array}$ & $\begin{array}{l}0.570 \\
(0.944)\end{array}$ & $\begin{array}{l}0.057 * \\
(1.499)\end{array}$ \\
\hline EDU & $\begin{array}{l}0.05 * * \\
(3.445)\end{array}$ & $\begin{array}{l}0.025^{* *} \\
(1.963)\end{array}$ & $\begin{array}{l}0.10^{*} \\
(4.829)\end{array}$ & $\begin{array}{l}0.078^{*} \\
(3.53)\end{array}$ & $\begin{array}{l}0.001 * * * \\
(2.098)\end{array}$ \\
\hline _CONS & $\begin{array}{l}0.097 * * * \\
(4.617)\end{array}$ & $\begin{array}{l}0.04^{* * * *} \\
(2.591)\end{array}$ & $\begin{array}{l}0.649^{*} \\
(8.421)\end{array}$ & $\begin{array}{l}0.511^{* * *} \\
(5.43)\end{array}$ & $\begin{array}{l}0.004 * * * \\
(7.761)\end{array}$ \\
\hline $\mathrm{R}^{2}$ & 0.7682 & 0.7682 & 0.1109 & 0.5931 & 0.7682 \\
\hline
\end{tabular}

Table 3. Regression results and robustness check

Notes: ***,**, * represent significance at $1 \%, 5 \%$, and $10 \%$, respectively. 
1. The scale of an independent brand automobile company has a positive impact on corporate performance. The automobile company is categorized as a large manufacturing company, and daily operations require a large quantity of resources and assets. The bigger the company is, the more resources the company can utilize at the same time, and its profitability and ability to withstand debt are stronger, so the performance is higher accordingly.

2. Growth rates of total assets and net assets reflect the growth of the company. With evidence from five different empirical methods, in most cases, the relationship between growth and performance is significant at a significance of $1 \%$. It follows then, that a company with strong growth has a better management system. In other words, the increase in total assets has a significant effect on overall corporate performance.

3. Profit margin of core business and operating profit margin have positive influences on corporate performance. They have very similar effects.

4. The turnover rate of accounts receivable and the inventory turnover rate reflect the position of capital flows. In the empirical analysis, the two do not have a significant influence on corporate performance. Thus, there is not necessarily a link between the turnover rate of accounts receivable and the market position, so that the inventory turnover rate only shows the managerial condition of the supply chain. Nevertheless, the relationship to corporate performance remains unclear.

5. Quick ratio and current ratio are important indicators of short-term solvency. Empirical results show that the current ratio stands at a significance of $1 \%$, while the quick ratio significance stands at 5\% as well. Hence, a positive relationship exists between solvency and corporate performance. Maintaining healthy short-term solvency can thus avoid bankruptcy and disruption of cash flow.

6. Although the input of R\&D has a lag effect, empirical results find that $R \& D$ investment has a significance of $1 \%$. It shows that $R \& D$ investment of China's independent brand automobile company has a great positive impact on corporate performance. A high level of R\&D investment can contribute to huge return in the subsequent accounting periods.

7. The proportion of sales from the top five customers has no significant effect on corporate performance.

8. The proportion of highly educated staff has a strong positive impact on overall corporate performance, and the variable is significant at a $1 \%$ significance level in all five regressions. The initiative brought by highly educated staff is a precious intellectual resource of the company, and this invisible resource can bring huge profits in daily operations.

\section{Policy Implication}

China's independent brand automobile companies should increase investment in assets to expand the size of the company. The scale of total assets directly determines the annual productivity of company and the size of market, and the size of the market directly determines the company's market position, brand power and profitability. There are mainly two ways that a company can expand its existing scale: debt financing and equity financing. For debt financing purposes, managers should, on the basis of stable business growth and to a reasonable extent, raise the debt ratio accordingly. In terms of equity financing, private companies can go public if operating conditions permit, thereby using the large amount of share capital from the market for expansion.

China's independent brand automobile companies should increase the proportion of R\&D investment intensity. Empirical results show that intensity of $R \& D$ investment has a strong overall positive impact on the corporate performance of China's independent brand automobile companies. Companies whose R\&D investment account for a large proportion of operating profit have strong competition of core technology, leading to high annual returns. At the national level, the government can increase R\&D tax relief or subsidize technological innovations to encourage $R \& D$ input of China's independent brand automobile companies.

China's independent brand automobile companies should pay careful attention to the positive impact of human and intellectual resources on corporate performance. When recruiting employees, they should employ more highly skilled workers and highly educated employees to improve the quality of human capital.

\section{Conclusion}

This paper utilizes panel data of China's independent brand automobile companies from 2012 to 2016. By means of the fixed effect model with control of heteroskedasticity, this paper analyzes the relationship between corporate performance and capital scale, enterprise growth rate, capital turnover rate, enterprise solvency, research and development expenditure input intensity, sales channel, human resources etc.. It finds that the scale of total assets, profit margins of core business, operating profit margins and short-term solvency can promote the corporate 
performance on the part of independent brand automobile companies. In addition, the R\&D investment intensity and qualifications of staff have very strong positive impacts on corporate performance. This paper therefore recommends that companies should, with controls for risks, expand the size of the company, increase R\&D investment to increase innovation and control costs, and improve the overall educational level of staff.

\section{References}

Chen, X. L. (2015). Research on the Influence Mechanism of Strategic Orientation and Innovation Model on Enterprise Performance (in Chinese). Zhejiang University.

Han, X. M. (2011). Analysis on the Relationship between Capital Structure and Enterprise Performance of Listed Companies in China (in Chinese). Liaoning University of Engineering and Technology.

Lebas, M. J. (1995). Performance Measurement and Performance Management. International Journal of Production Economics, 41(1-3), 23-35.

Li, W. (2009). Empirical Study on the Impact of Capital Structure of Listed Companies on the Performance of China's Automobile Manufacturers (in Chinese). Northeast Normal University.

Li, X. T., \& Zhang, X. (2010). Empirical Study on Human Capital and Enterprise Performance of Listed Companies (in Chinese). Shandong Institute of Economics.

Yang, M. L. (2010). Research on the Formation of Intellectual Capital and Its Evaluation Index System of High-Tech Enterprises (in Chinese). Market Modernization, 36, 67-68.

Zhong, C. Q. (2016). Research on the Impact of Technological Innovation on Business Performance of Listed Companies in China (in Chinese). Beijing University of Chemical Technology. 